This Accepted Author Manuscript is copyrighted and published by Elsevier. It is posted here by agreement between Elsevier and University of Brasilia. Changes resulting from the publishing process - such as editing, corrections, structural formatting, and other quality control mechanisms - may not be reflected in this version of the text. The definitive version of the text was subsequently published in [Micron, Volume 39, Issue 7, October 2008, Pages 915-925, doi:10.1016/j.micron.2007.11.012].You may download, copy and otherwise use the AAM for non-commercial purposes provided that your license is limited by the following restrictions:

(1) You may use this AAM for non-commercial purposes only under the terms of the CC-BY-NCND license.

(2) The integrity of the work and identification of the author, copyright owner, and publisher must be preserved in any copy.

(3) You must attribute this AAM in the following format: [agreed attribution language, including link to CC BY-NC-ND license + Digital Object Identifier link to the published journal article on Elsevier's ScienceDirect ${ }^{\circledR}$ platform].

Este Manuscrito do Autor Aceito para Publicação (AAM) é protegido por direitos autorais e publicado pela Elsevier. Ele esta disponível neste Repositório, por acordo entre a Elsevier e a Universidade de Brasília. As alterações decorrentes do processo de publicação - como a edição, correção, formatação estrutural, e outros mecanismos de controle de qualidade - não estão refletidas nesta versão do texto. A versão definitiva do texto foi posteriormente publicado em [Micron, Volume 39, Número 7, Outubro 2008, Pages 915-925, doi:10.1016/j.micron.2007.11.012]. Você pode baixar, copiar e utilizar de outra forma o AAM para fins não comerciais, desde que sua licença seja limitada pelas seguintes restrições:

(1) Você pode usar este AAM para fins não comerciais apenas sob os termos da licença CC- BYNC-ND.

(2) A integridade do trabalho e identificação do autor, detentor dos direitos autorais e editor deve ser preservado em qualquer cópia.

(3) Tem de atribuir este AAM no seguinte formato: [acordo na linguagem atribuída, incluindo o link para CC BY-NC-ND licença Digital + DOI do artigo publicado na revista Elsevier ScienceDirect ${ }^{\circledR}$ da plataforma]. 


\title{
Ultrastructural description and cytochemical study of the spermatozoon of Crotallus durissus (Squamata, Serpentes)
}

\author{
L.D. Cunha \\ L. Tavares-Bastos
}

S.N. Báo

\begin{abstract}
The present study was undertaken to elucidate some aspects about the nature of the spermatozoon ultrastructure of Crotallus durissus using cytochemical methods. We also provide for the first time the ultrastructural description of this species spermatozoon. Cytochemical studies of spermatozoa have not been performed so far in the Serpentes, and species spermatozoon may prove helpful to better understand the reproductive biology of this group. Besides the synapomorphies of the Squamata and Serpentes, the C. durissus spermatozoon possess the following: circular acrosome tip; rounded perforatorium tip with a stopper-like basal modification; bilateral stratified laminar structures; central electron-dense structure within the proximal centriole; fibrous sheath extending until the level of the second mitochondrial ring; rounded mitochondria in cross-section, but with variable shape and organization in longitudinal and oblique sections, respectively; linear annulus; developed multilaminar membranes in the nuclear region and the midpiece. The formation of membrane filipin-sterol complexes occur sparsely along the head region, specially around the nucleus; the complexes were also present in the midpiece membrane and scarcely lining the flagellum. The complexes were present in the different layers of the multilaminar membranes. The ethanolphosphotungstic acid (E-PTA) treatment releaved the presence of basic proteins in acrosome vesicle, pericentriolar material, peripheral fibers of the axoneme and fibrous sheath. The tannic acid technique revealed the microtubules of the centrioles and the axoneme; the extracellular tubules encircling the spermatozoa and those spread in the epididymal lumen were also observed. However, the immunocytochemistry assay using antibodies against alphatubulin and beta-tubulin, the primary microtubule monomers, does not support the existence of composition similarity between these tubular structures, since the extracellular tubules were not labeled by the antibodies. The results obtained in this work demonstrate that the utilization of electron microscopic techniques may provide relevant information to the study of ophidian reproductive biology, particularly in analyses concerning spermatozoal ultrastructure.
\end{abstract}

Keywords: Snakes; Spermatozoa; Ultrastructure; Cytochemistry; E-PTA; Filipin; Tannic acid; Immunocytochemistry

\section{Introduction}

In the last decades, the reproductive biology of the Serpentes has been receiving particular attention due to the perception that the reproductive modes and strategies of this group are extremely variable (Shine and Bonnet, 2000 and Shine, 2003). In this sense, the morphological variability of spermatozoa, not only in the Serpentes but in members of the Squamata as a whole, can be associated with the reproductive characteristics of their species (Vieira et al., 2004), which are subject to a high degree of variation between one another such 
as: enzymes associated with the transport of sperm, sperm storage places in the female reproductive tract (Olsson et al., 1994, Almeida-Santos and Salomão, 1997, Blackburn, 1998 and Server and Hamlett, 2002), fertilization process, place of fertilization (Blackburn, 1998), oviduct or sperm secretions for sperm maintenance in the female reproductive tract, and the mechanism of sperm release from storage regions (Girling, 2002).

For Squamates in general, including snakes, ultrastructural descriptions of spermatozoon tend to focus on aspects that may be useful in phylogenetic analysis of the group, since this gamete ultrastructure has been considered a promising source of characters to the comprehension of phylogenetic relationships in the Squamata (Teixeira et al., 1999 and Giugliano et al., 2002, Tavares-Bastos et al., 2002 and Vieira et al., 2004). Nevertheless, ultrastructural descriptions of the spermatozoon in species of snakes are restricted to a few works, including: Austin (1965), Hamilton and Fawcett (1968), Furieri (1970), Jamieson and Koehler (1994), Jamieson (1995), Harding et al. (1995), Oliver et al. (1996), Tourmente et al. (2006), Tavares-Bastos et al. (2007). On the other hand, the knowledge concerning the relevance of structural aspects of the gamete to guarantee the fertilization success is still limited.

Cytochemical methods in electron microscopy are a common tool employed in the study of sperm ultrastructure in diverse groups, including invertebrates (Báo et al., 1992, Báo and Souza, 1992, Lino-Neto et al., 2000 and Zama et al., 2007). The cytochemistry can provide information about a cell structure that may more securely substantiate inferences related to the origins and functions of the diverse components of the spermatozoon, which consequently would augment the comprehension of reproductive biology of species.

The spermatozoon of snakes presents ultrastructural peculiarities that have no description of their nature yet. Analyzing cytochemical aspects of the snake spermatozoa may prove helpful to better understand its structure in the context of the variability in the reproductive biology of this group. Therefore, the aim of this work is to elucidate some aspects about the nature of the spermatozoon ultrastructure of Crotallus durissus, applying cytochemical methods for this species for the first time. Besides that, we provide the ultrastructural description of $\mathrm{C}$. durissus spermatozoon.

\section{Materials and methods}

Adult C. durissus males (RGI 1707 and RGI 1710-Zoológico de Brasília) had been obtained from the Zoológico de Brasília, being both brought to the Zoológico from the vicinity of Brasília City, central Brazil $\left(15^{\circ} \mathrm{S}, 47^{\circ} \mathrm{W}\right)$. The specimens were euthanized with intracardial 
administration of Tiopental ${ }^{\circledR}$ and potassium chloride. The distal portions of their epididymides were removed by dissection and diced in small pieces $(1-3 \mathrm{~mm} 2)$.

\subsection{Light microscopy}

Glutaraldehyde-paraformaldehyde fixed epididymides smears were placed on glass slides and dried at room temperature. Next, the slides were incubated for $15 \mathrm{~min}$ in PBS containing $2 \mu \mathrm{g} / \mathrm{ml}$ of 4'6-diamidino-2-phenilindol (DAPI) (Sigma-Aldrich), washed with distilled water and protected with glass covers. The slides were subsequently observed using a Zeiss Axiophot microscope equipped with 360-370 nm excitation filter, which allows for visualizing the fluorescence of the nuclear stain DAPI. Images under Nomarski interferential contrast were also acquired.

\subsection{Transmission electron microscopy}

\subsubsection{Conventional method}

Tissues were fixed for $24 \mathrm{~h}$ at $4{ }^{\circ} \mathrm{C}$ in a solution containing $2 \%$ glutaraldehyde, $2 \%$ paraformaldehyde and $3 \%$ sucrose in $0.1 \mathrm{M}$ sodium cacodylate buffer, $\mathrm{pH}$ 7.2. Samples were subsequently rinsed in $0.1 \mathrm{M}$ sodium cacodylate buffer, $\mathrm{pH} 7.2$, and post-fixed for $1 \mathrm{~h}$ with $1 \%$ osmium tetroxide, $0.8 \%$ potassium ferricyanide and $5 \mathrm{mM}$ calcium chloride in $0.1 \mathrm{M}$ sodium cacodylate buffer, $\mathrm{pH}$ 7.2. Next, they were dehydrated in a series of ascending concentration acetone solutions (30-100\%) and embedded in Spurr's epoxy resin. Ultrathin sections were stained with uranyl acetate and lead citrate, then observed and photographed using a Jeol ${ }^{\circledR}$ 1011 transmission electron microscope.

\subsubsection{Ultrastructural cytochemistry}

Basic proteins in spermatozoa were detected by the ethanol-phosphotungstic acid (EPTA) technique. Fragments of epididymides were fixed for $4 \mathrm{~h}$ at $4{ }^{\circ} \mathrm{C}$ with $2.5 \%$ glutaraldehyde, $5 \%$ sucrose in $0.1 \mathrm{M}$ sodium phosphate buffer, $\mathrm{pH}$ 7.4. They were then rinsed in $0.1 \mathrm{M}$ sodium phosphate buffer, $\mathrm{pH} 7.4$, dehydrated in an ethanol series (30-90\%) and treated in bloc with $2 \%$ E-PTA for $6 \mathrm{~h}$ at $4{ }^{\circ} \mathrm{C}$. After rinsing in absolute ethanol, the fragments were embedded in Spurr's resin. 
For the detection of sterols in the spermatozoon, samples were fixed for $4 \mathrm{~h}$ at room temperature in solution $2.5 \%$ glutaraldehyde in $0.1 \mathrm{M}$ sodium cacodylate buffer, $\mathrm{pH} 7.2$, containing $100 \mu \mathrm{g} / \mathrm{ml}$ of filipin (Sigma-Aldrich), which was initially dissolved in dimethyl sulfoxide (DMSO) at a final concentration of $0.5 \%$. The material was subsequently rinsed in 0.1 $\mathrm{M}$ sodium cacodylate buffer, $\mathrm{pH} 7.2$, and post-fixed for $1 \mathrm{~h}$ with $1 \%$ osmium tetroxide, $0.8 \%$ potassium ferricyanide and $5 \mathrm{mM}$ calcium chloride in $0.1 \mathrm{M}$ sodium cacodylate buffer, $\mathrm{pH}$ 7.2. After being rinsed again in sodium cacodylate buffer, the tissues were dehydrated in acetone (30-100\%) and embedded in Spurr's resin.

For the treatment with tannic acid, tissue samples were fixed over 7 days at $4{ }^{\circ} \mathrm{C}$ with $2 \%$ glutaraldehyde, $1 \%$ tannic acid, $3 \%$ sucrose in $0.1 \mathrm{M}$ sodium phosphate buffer, $\mathrm{pH}$ 7.2. The material was subsequently rinsed in distilled water, stained in bloc overnight in $1 \%$ uranyl acetate, dehydrated in acetone (30-100\%) and embedded in Spurr's resin.

For all the treatments, ultrathin sections, with or without further staining by uranyl acetate and lead citrate, were observed and photographed in a Jeol ${ }^{\circledR} 1011$ transmission electron microscope.

\subsubsection{Ultrastructural immunocytochemistry}

The specimens were fixed for $5 \mathrm{~h}$ at room temperature in a solution containing $0.5 \%$ glutaraldehyde, $4 \%$ paraformaldehyde, $0.2 \%$ picric acid in $5 \%$ sucrose and $5 \mathrm{mM}$ calcium chloride in $0.1 \mathrm{M}$ sodium cacodylate buffer, $\mathrm{pH}$ 7.2. After being rinsed in the same buffer overnight at $4{ }^{\circ} \mathrm{C}$, free aldehyde groups were quenched with ammonium chloride in this buffer for $1 \mathrm{~h}$ at $4{ }^{\circ} \mathrm{C}$. The material was stained in bloc with $2 \%$ uranyl acetate in $15 \%$ acetone for $2 \mathrm{~h}$ at $4{ }^{\circ} \mathrm{C}$, subsequently dehydrated in acetone (30-100\%) and embedded in LRGold resin.

Ultrathin sections were collected on nickel grids and pre-incubated in phosphate saline buffer (PBS) containing $1.5 \%$ bovine albumin (PBS-BSA) and $0.01 \%$ Tween 20, and subsequently incubated for $1 \mathrm{~h}$ with monoclonal antibodies against alpha-tubulin (clone DM 1A-Sigma) and beta-tubulin (clone TUB 2.1-Sigma) diluted 1:100 in PBS-BSA. After rinsing in PBS-BSA, the grids were incubated for $1 \mathrm{~h}$ with labeled secondary antibodies (mouse-lgG-Auconjugated 10nm-Sigma) diluted 1:20 in PBS-BSA. Finally, the grids were washed with PBS and distilled water, stained with uranyl acetate and lead citrate and observed and photographed in a Jeol ${ }^{\circledR} 1011$ transmission electron microscope. 


\section{Results}

A generalized C. durissus spermatozoon is represented diagrammatically in Fig. 1. The spermatozoon of this species is filiform and consists of three regions, distinguished in light microscopy: head (acrosome and nucleus), midpiece and tail ( Fig. 2A and B). The gamete measures approximately $42.5 \mu \mathrm{m}$ in total length.

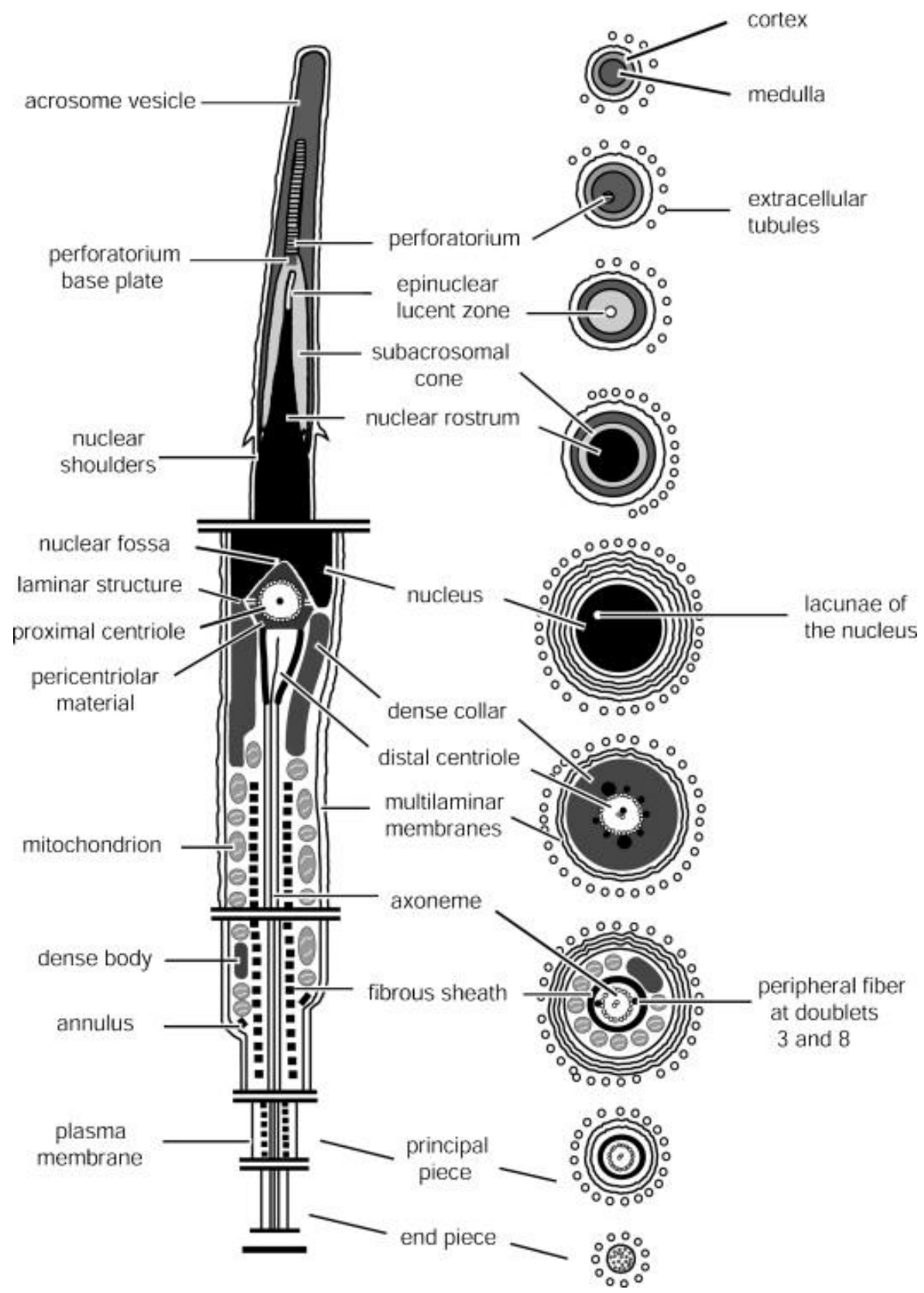

Fig. 1. Schematic drawing of mature spermatozoon of Crotallus durissus in longitudinal section and each corresponding transverse section. The structures were drawn in an approximate proportion and scales of various components are only approximate. Scale bar $10 \mu \mathrm{m}$. 


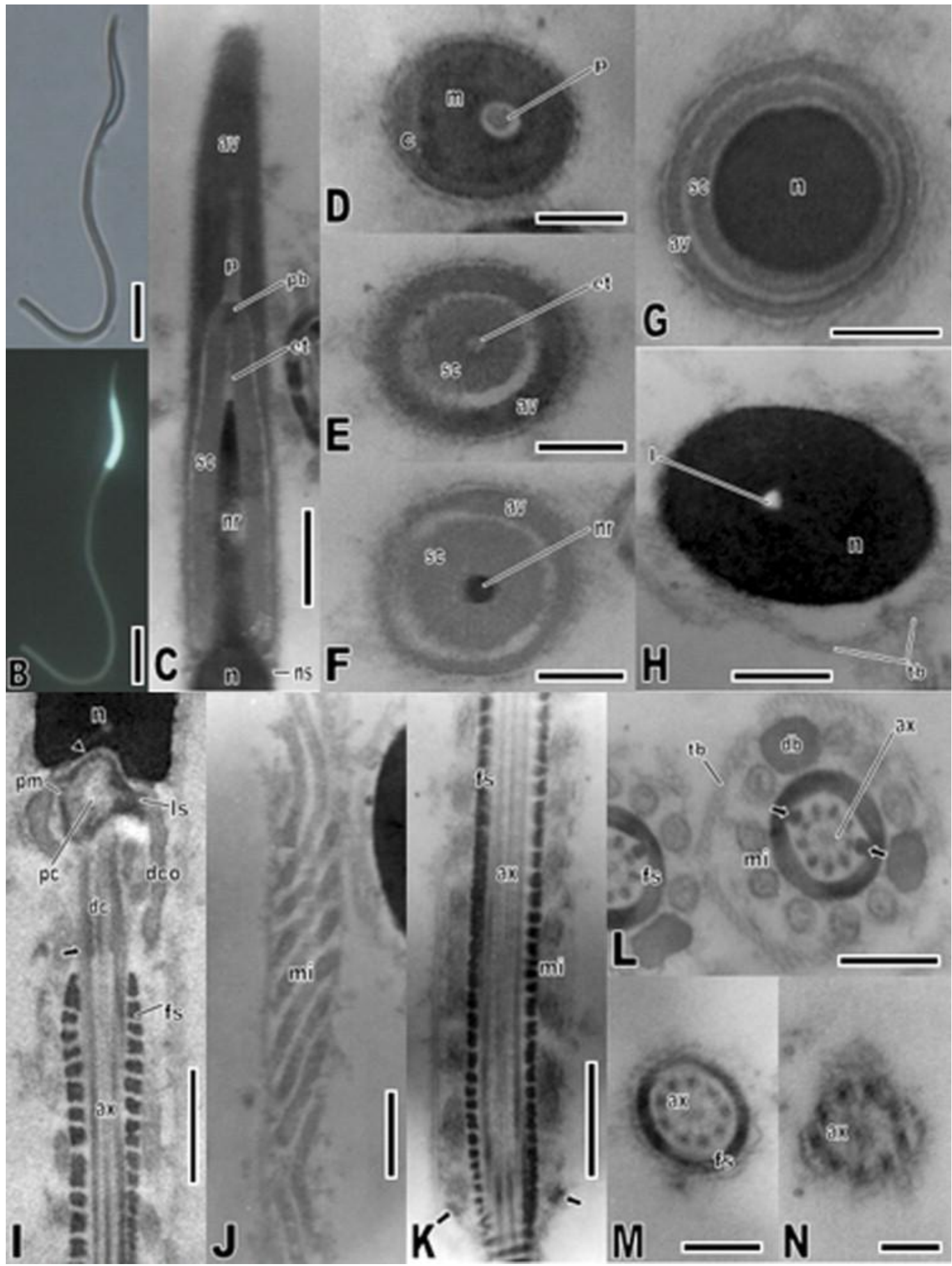

Fig. 2. Spermatozoon of Crotallus durissus. Light micrographs captured under Normaski interferential contrast (A) and fluorescence (B), showing head, midpiece and tail. (C-H) Transmission electron micrographs of the head (acrosome complex and nucleus). (C) Longitudinal section through the acrosome complex, showing acrosome vesicle, subacrosomal cone, epinuclear lucent zone, perforatorium with a rounded tip, stopper-like perforatorium base plate, nuclear rostrum, nucleus, nuclear shoulders. (D) Cross-section through the perforatorium level, showing a circular acrosome vesicle subdivided in cortex and medulla. (E) Cross-section through the epinuclear lucent zone, showing acrosome vesicle and subacrosomal cone. (F) Cross-section through the nuclear rostrum tip level, showing the acrosome vesicle and paracrystalline subacrosomal cone. (G) Cross-section through the level of the nuclear rostrum posterior region, showing reduced acrosome vesicle and subacrosomal 
cone. $(\mathrm{H})$ Cross-section through the nucleus showing the nuclear lacuna; note the presence of extracellular tubules. (I-N) Transmission electron micrographs of the midpiece and tail. (I) Longitudinal section of the midpiece, showing the nuclear fossa (arrowhead), pericentriolar material, and bilateral stratified laminar structure, proximal centriole, distal centriole, peripheral fibers (arrow), axoneme dense collar and fibrous sheath. (J) Oblique section through the midpiece, showing the mitochondria arrangement. (K) Longitudinal section through the midpiece bottom, showing axoneme, fibrous sheath, mitochondria and linear annulus (arrow). (L) Cross-section through the midpiece, showing axoneme, dense bodies, rounded mitochondria and extracellular tubules; note the enlarged 3 and 8 peripheral fibers (arrows). (M) Cross-section through the principal piece of the tail, showing axoneme and fibrous sheath. (N) Cross-section through the tail endpiece, which comprises only the axoneme. Abbreviations: an = annulus; $\mathrm{av}=$ acrosome vesicle; $\mathrm{ax}=$ axoneme; $\mathrm{c}=$ cortex of the acrosome vesicle; $\mathrm{dc}=$ distal centriole; $\mathrm{db}=$ dense body; $\mathrm{dco}=$ dense collar; et = epinuclear lucent zone; $\mathrm{fs}=$ fibrous sheath; $\mathrm{I}=$ nuclear lacuna; Is = stratified laminar structure; $\mathrm{m}=$ medulla of the acrosome vesicle; $\mathrm{mi}=$ mitochondria; $\mathrm{n}=$ nucleus; $\mathrm{nr}=$ nuclear rostrum; $\mathrm{ns}=$ nuclear shoulder; $\mathrm{p}=$ perforatorium; $\mathrm{pb}=$ perforatorium base plate; $\mathrm{pc}=$ proximal centriole; $\mathrm{pm}=$ pericentriolar material; $\mathrm{sc}=$ subacrosomal cone; $\mathrm{tb}=$ extracellular tubules. Scale bars: $C, I-K=0.5 \mu \mathrm{m} ; \mathrm{H}$ and $\mathrm{L}=0.3 \mu \mathrm{m} ; \mathrm{D}-\mathrm{G}, \mathrm{M}=0.2 \mu \mathrm{m} ; \mathrm{N}=0.1 \mu \mathrm{m}$.

\subsection{Spermatozoon ultrastructure}

The acrosome complex comprises the anterior portion of the head (Fig. 2C) and consists of two caps, the external and more electron-dense acrosomal vesicle and the internal subacrosomal cone (Fig. 2D-G). In transversal sections, the anteriormost region of the acrosome appears circular (Fig. 2 and Fig. 3), and it is possible to distinguish two different portions in the acrosome vesicle: a thinner external cortex and a slightly more electron-dense medulla (Fig. 2D). Within the medulla, there is a single perforatorium (Fig. 2 and Fig. 3), which possess a rounded tip and a stopper-like basal modification inserted into the apical portion of the subacrosomal cone (Fig. 2C). It has not been observed any kind of ridge in the acrosome vesicle structure (Fig. $2 \mathrm{E}$ and F). The subacrosomal cone presents a homogeneous paracrystalline aspect and covers the anterior region of the nucleus, the nuclear rostrum (Fig. 2C, F and G). Intervening between these two structures, there is an epinuclear electron-lucent zone (Fig. 2C and E). The posterior extremity of the acrosome is marked by the presence of two small and bilateral electron-dense protuberances localized above the nuclear shoulders (Fig. 2C). 


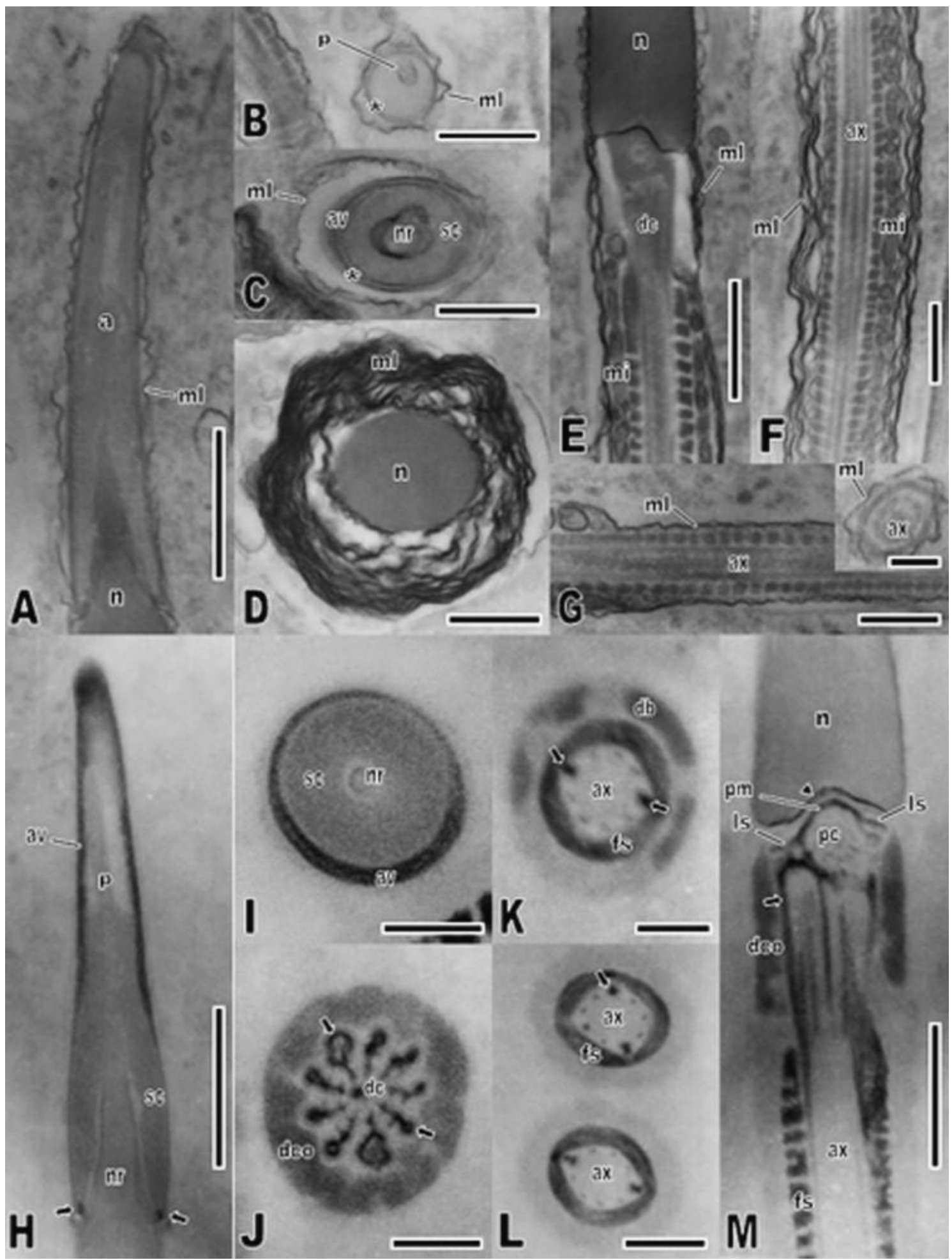

Fig. 3. Thin sections of filipin and ethanolic phosphotungstic acid (E-PTA)-treated spermatozoon of C. durissus in transmission electron microscopy. (A-G) Filipin-treated spermatozoon showing the characteristic wavy configuration induced by the formation of filipin-sterol complexes in the multilaminar membranes. (A) Longitudinal section through the acrosome. (B) Transverse section through the acrosome vesicle at the perforatorium level; note the complex absence in the acrosome membrane (asterisk). (C) Transverse section through the acrosome at the nuclear rostrum tip, without any complex in the acrosome membrane (asterisk). (D) Transverse section through the nucleus; note the higher amount of multilaminar membranes comparing with the acrosome region, and the intense wavy configuration in most of these membranes. (E) Longitudinal section through the transition between nucleus and midpiece; note the absence of filipin-sterols complexes in the mitochondria membranes. 
(F) Longitudinal section through the midpiece, showing developed multilaminar membranes with a considerably undulated by the presence of filipin-sterols complexes and no undulation in mitochondria membranes. (G) Longitudinal section and transverse section (inset) through the tail principal piece, showing the axoneme lined by minor-layered multilaminar membranes, slightly undulated. $(\mathrm{H}-\mathrm{M})$ Ultrastructural localization of basic proteins after treatment with E-PTA. (H) Longitudinal section through the acrosome, showing strongly stained acrosome vesicle except for the medulla closer to the perforatorium and the latter structure itself. Note the negative-stained subacrosomal cone and nucleus, and the presence of a small positive-stained region (arrow) in the acrosome end. (I) Transverse section through the acrosome at the nuclear rostrum level, showing the restriction of a stronger staining to the vesicle of the acrosome. (J) Transverse section through the midpiece in the distal centriole level, showing the intensively stained peripheral fibers (arrows) and the comparatively less-stained dense collar. ( $K$ and $L$ ) Transverse sections through the midpiece, showing the stained fibrous sheath and the slightly less-stained dense bodies in the periphery of the axoneme; note the staining of the reduced peripheral fibers and 3 and 8 fibers (arrow) of the axoneme. (M) Longitudinal section of the midpiece showing positive pericentriolar material, encircling the proximal centriole and lining the nuclear fossa (arrowhead), laminar stratified structure, peripheral dense fibers of the centriole (arrow) and fibrous sheath. Note the slightly less-stained dense collar. Abbreviations: av = acrosome vesicle; $a x=$ axoneme; $\mathrm{dc}=$ distal centriole; $\mathrm{db}=$ dense body; $\mathrm{dco}=$ dense collar; $\mathrm{fs}=$ fibrous sheath; $\mathrm{Is}=$ stratified laminar structure; $\mathrm{mi}=$ mitochondria; $\mathrm{ml}=$ multilaminar membranes; $\mathrm{n}=$ nucleus; $\mathrm{nr}=$ nuclear rostrum; $\mathrm{p}=$ perforatorium; $\mathrm{pc}=$ proximal centriole; $\mathrm{pm}=$ pericentriolar material; $\mathrm{sc}=$ subacrosomal cone. Scale bars: $A, E, F, H=1.0 \mu \mathrm{m} ; B-D, G, M=0.5 \mu \mathrm{m} ; \mathrm{L}=0.3 \mu \mathrm{m} ; \mathrm{G}$ (inset), $\mathrm{I}-\mathrm{K}=0.2 \mu \mathrm{m}$.

The nuclear shoulders mark the transition of the nucleus, from a narrower nuclear rostrum to a longitudinally cylindrical shape (Fig. 2C, F-H). The nucleus appears circular in cross-sections and surrounded solely by plasma membrane (Fig. $2 \mathrm{H}$ ). The nucleus possesses an extremely electron-dense and homogeneous appearance, except for an electron-lucent lacuna within it. At its base, the nucleus has a nuclear fossa that signals the transition from the head to the midpiece and shelters some pericentriolar material and part of the proximal centriole (Fig. 2l).

The beginning of the midpiece consists of the neck region, which is formed by the proximal and distal centrioles, the dense collar and most of the pericentriolar material (Fig. 2I). The electron-dense pericentriolar material conforms in shape to the nuclear fossa, surrounds the proximal centriole and extends posteriorly, projecting two bilateral stratified laminar structures from the proximal centriole border towards the dense collar (Fig. 2I). A central electron-dense structure lies within the proximal centriole (Fig. 4B). The centrioles present the typical ordering of nine microtubule triplets (Fig. 4B). Being the basal body of the axoneme, the distal centriole also possesses two central singlets of microtubules. The triplets of this centriole are each connected to an adjacent peripheral dense fiber, and there is an additional fiber accompanying the central singlets (Fig. 3J). The axoneme, identified by the presence of electron-dense fibrous sheath surrounding it (Fig. 2I), presents the $9+2$ pattern of double microtubules (Fig. 2 and Fig. 4). The peripheral fibers are still present, although they tend to narrow continuously along the midpiece length until they disappear but for fibers 3 and 8 , which persist, enlarged and disconnected from their respective doublets (Fig. $2 \mathrm{~L}$ ). The fibrous 
sheath extends forward until the level of the second mitochondrial ring in longitudinal sections (Fig. 3E). The mitochondria are organized around the axoneme and juxtapose the fibrous sheath (Fig. 2 and Fig. 3). Whereas they appear rounded in cross-sections (Fig. 2L), their form varies between rounded and columnar structures longitudinally (Fig. 3E). Their form also varies in oblique sections, from slightly short and straight tubules to sinuous tubules in a zig-zag arrangement (Fig. 2J). Interspersed among the mitochondria, there are a reduced number of electron-dense dense bodies, which are columnar longitudinally and do not form complete rings in transversal sections (Fig. 2L). The midpiece ends posteriorly with the annulus, an electron-dense and size-reduced structure, but whose shape can be identified as linear (Fig. $2 \mathrm{~K})$.

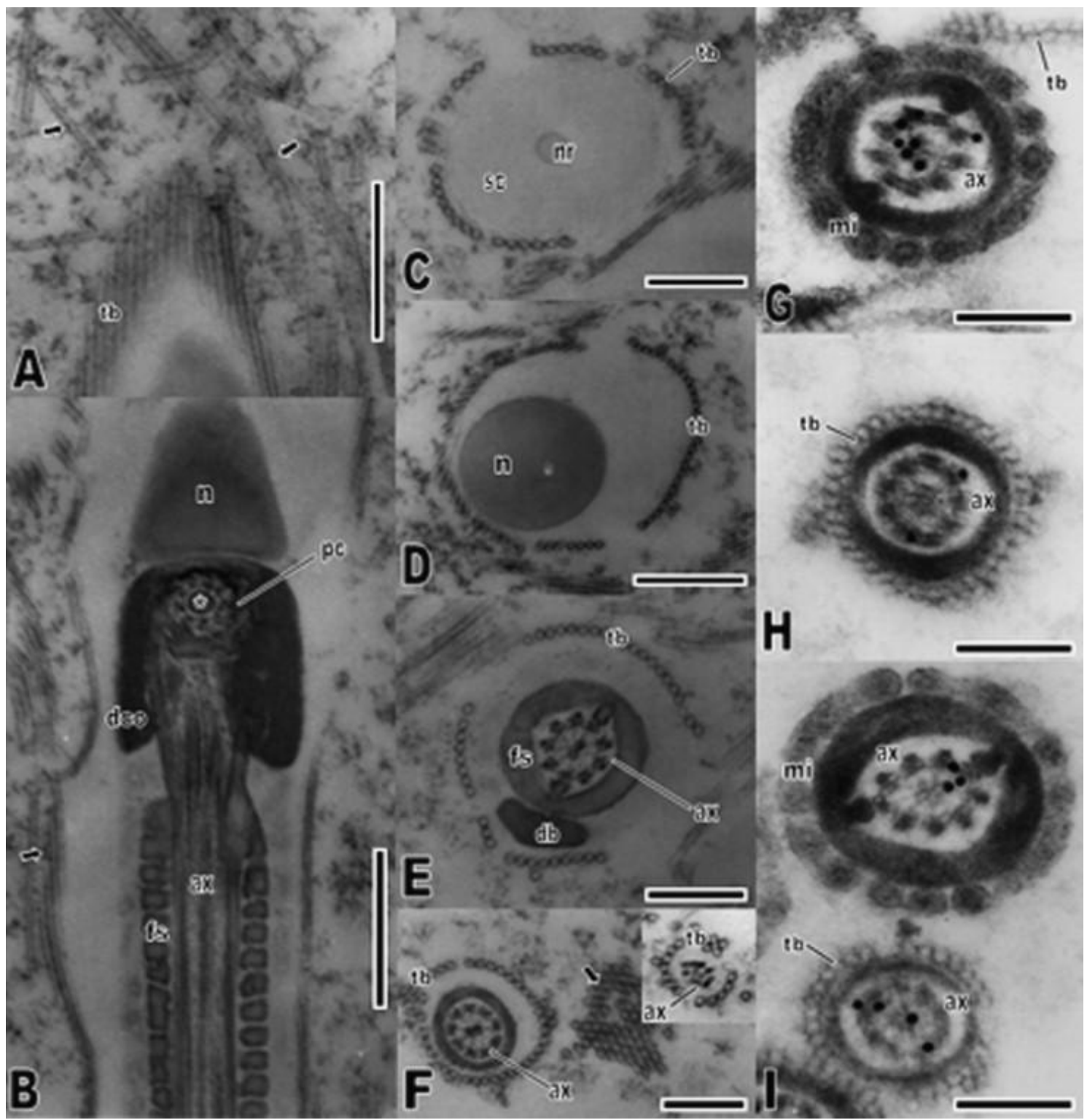

Fig. 4. Transmission electron micrographs of tannic acid treatment and immunolocalization of tubulins in Crotallus durissus spermatozoon. (A-F) Ultrastructural identification of tubular structures stained with tannic acid. (A) Oblique section through the nucleus, showing the longitudinal lining of strongly stained extracellular tubules and the presence of similar tubules spread in the epididymidal lumen 
(arrows). (B) Longitudinal section of the midpiece evidencing the microtubule arrangement in the proximal centriole; note the presence of an electron-dense structure lying within this centriole (asterisk). Lining the spermatozoon structure, it is observed a tubular structure (arrow). (C) Transverse section through the acrosome in the nuclear rostrum level, showing the organized circular arrangement of extracellular tubules around the spermatozoon. (D) Transverse section of the nucleus, evidencing the presence of the extracellular tubules in this region. (E) Transverse section of the midpiece, showing the arrangement of microtubules in the axoneme, which is juxtaposed by the fibrous sheath. Note that the extracellular tubules are also present around the midpiece. (F) Transverse section of the tail principal piece and end piece (inset), demonstrating the presence of extracellular tubules along the spermatozoon length. Note the transverse sectioned tubules in the epididymides lumen (arrow). (G-I) Immunocytochemical localization of alpha-tubulin ( $\mathrm{G}$ and $\mathrm{H}$ ) and beta-tubulin ( $\mathrm{I}$ ) monomers in transverse sections of the midpiece ( $\mathrm{G}$ and $\mathrm{I}$ ) and principal piece $(\mathrm{H}$ and $\mathrm{I})$. Note that the labeling is restricted to the axoneme microtubules, and no labeling is found in the extracellular tubules. Abbreviations: $a x=$ axoneme; $\mathrm{db}=$ dense body; $\mathrm{dco}=$ dense collar; $\mathrm{fs}=$ fibrous sheath; $\mathrm{mi}=$ mitochondria; $\mathrm{n}=$ nucleus; $\mathrm{pc}=$ proximal centriole; $\mathrm{sc}=$ subacrosomal cone; $\mathrm{tb}=$ extracellular tubules. Scale bars: $\mathrm{A}$ and $\mathrm{B}, \mathrm{D}=0.5 \mu \mathrm{m} ; \mathrm{C}$, $E$ and $F=0.3 \mu \mathrm{m} ; \mathrm{G}-\mathrm{I}=0.2 \mu \mathrm{m}$.

The tail is divided in principal piece and end piece. The principal piece is formed by the plasma membrane, the fibrous sheath and the axoneme (Fig. 2M). Along the tail, the amount of cytoplasm is continuously reduced, the same true to the fibrous sheath diameter. At the end piece, there are only the axoneme and the plasma membrane and the diameter of the tail is reduced (Fig. 2N).

The plasma membrane is organized in a complex composed of a variable number of layers depending on the region of the spermatozoon. The multilaminar membranes are more developed surrounding the nucleus (Fig. 3D), but a high number of layers is found in the midpiece too (Fig. 3F). The membranes were better observed in tissues treated with filipin. The acrosome and the tail are distinctly poor in multilaminar membranes (Fig. 3A-C and G). All along the spermatozoon length is observed the presence of tubules encircling its structure externally, although these tubules are also present spread in the epididymidal lumen (Fig. 4AF).

\subsection{Cytochemistry}

In filipin-treated tissues, it was possible to visualize the characteristic wave configuration induced by the formation of filipin-sterol complexes in the membranes of spermatozoa (Fig. 3A-G). The hemispherical bulges were seen mainly in the membranes lining the head region, around the nucleus especially (Fig. 3A-D). However, the formation of filipinsterol complexes also occurred in the midpiece membrane (Fig. 3E and F). The membrane lining the flagellum was markedly poorer in complexes (Fig. 3G). Noticeably, the complexes formation occurred both in regions where the multilaminar membranes are not developed, as the acrosome and the flagellum, and regions where it presents many layers, as the nucleus and 
the midpiece. In addition, the complexes were present in the different layers of the multilaminar membranes. It was not observed any difference in complexes abundance between the tip and the more posterior portions of the acrosome (Fig. $3 \mathrm{~A}$ ). The internal membranes, including those which line the subacrosomal cone, the nucleus (at least along the nuclear rostrum length) and the mitochondrial membranes do not present the hemispherical bulges (Fig. 3B and $\mathrm{C}$ and $\mathrm{E}$ ). There was no labeling of the extracellular tubules.

The E-PTA treatment revealed various structures of the spermatozoon that may be characterized as basic proteins rich because of their increased electron-density due to the treatment (Fig. $3 \mathrm{H}-\mathrm{M})$. In the acrosome, the region corresponding to the acrosomal vesicle was intensely labeled, except for the medulla closer to the perforatorium and for the latter structure itself (Fig. 3H and I). The subacrosomal cone showed reduced electron-density, albeit its most posterior portion, where it fuses with the vesicle, presents a small region extremely electron-dense (Fig. 3H). In the midpiece, the pericentriolar material, the peripheral fibers and the fibrous sheath were strongly labeled (Fig. 3M). The peripheral fibers and the fibrous sheath maintained their labeling along the spermatozoon until they disappear, although its intensity was gradually reduced (Fig. 3J-M). The dense collar and the dense body present a very similar slight labeling (Fig. $3 \mathrm{~J}$ and $\mathrm{K}$ ). Once more there was any labeling of the extracellular tubules.

The treatment with tannic acid, which is aimed to detect tubular structures, revealed both the microtubules, which form the centrioles and the axoneme, and the extracellular tubules (Fig. 4A-F). Even though these tubules have been demarcated apparently free in the epididymal lumen, without any organization, they were unequivocally ordered encircling the spermatozoon all along its length, longitudinally or in cross-sections.

\subsection{Immunocytochemistry}

Ultrathin sections embedded in LRGold resin were used to identify the presence of tubulins, which are the most abundant proteins assembled in the microtubules (Fig. 4G-I). The antibodies against alpha-tubulin (Fig. $4 \mathrm{G}$ and H) and beta-tubulin (Fig. 4I), the main isoforms of tubulin monomers, labeled the microtubules along the axoneme. By contrast, there was no detectable labeling of the extracellular tubules. 


\section{Discussion}

The ultrastructure of the $\mathrm{C}$. durissus spermatozoon is described for the first time in the present work. The spermatozoon bears the characteristics recognized as synapomorphies of Squamata, which have already been specified in many previous works ( Healy and Jamieson, 1994, Harding et al., 1995, Jamieson, 1995, Jamieson, 1999 and Oliver et al., 1996). Besides that, the following spermatozoon synapomorphies of Serpentes are present in C. durissus ( Oliver et al., 1996 and Jamieson, 1999): presence of dense collar, multilaminar membranes and extracellular tubules; reduction of the perforatorium base plate; and the unusual elongation of the midpiece. According to Jamieson (1995), Oliver et al. (1996), Teixeira et al. (1999), Giugliano et al. (2002) and Vieira et al. (2004), the spermatozoa ultrastructure is a relevant source of characters for use in phylogenetic analysis of Squamata, although the number of species for which the gamete ultrastructure is described must be augmented. Since descriptions concerning Serpentes spermatozoa are even scarcer, the present work may contribute to resolve phylogenetic relationships of this group in the future.

The multilaminar membranes are present in the epidydimal spermatozoa of all Serpentes species analyzed until now. Some hypotheses have been suggested to explain their origins and functions, but none of them has been experimentally tested yet. Hamilton and Fawcett (1968) suggested that the multilaminar membranes could constitute a source of phospholipids to warrantee the motility of the gamete, and even recent works support this hypothesis (Tourmente et al., 2006). The elevated amount of mitochondria stored in an unusual elongated midpiece would indicate high levels of energy production, which would explain the necessity of providing an extra source of energy to sustain these metabolic capacities (Oliver et al., 1996 and Tourmente et al., 2006).

On the other hand, at least in C. durissus, it is observed that the multilaminar membranes present a greater number of layers around the nuclear region, albeit they are also abundant in the midpiece. Thus it is possible that they are related to other functions than supplying a high energetic demand. Indeed, maintaining polarization in a cell whose levels of gene transcription and protein translation are extremely low, as an spermatozoon with high level of chromatin compaction, may depend on the heterogeneous distribution of its membrane components (phospholipids, proteins, sterols and glycolipids) (Ladha, 1998). In mammals, the analysis of the sterols distribution in spermatozoan membrane have been shown that their presence is related to the establishment of distinct structural domains along the spermatozoan surface, which can vary according to the maturation process through the epididymides in a species-specific way ( Ladha, 1998 and Travis and Kopf, 2002). In addition, 
sperm membrane cholesterol efflux regulates sperm capacitation during residence the female reproductive tract (Travis and Kopf, 2002). The polyenic antibiotic filipin has been largely employed, mainly in freeze-fracture studies, to allow visualizing biological membrane sterols, based on the formation of filipin-sterol complexes (Elias et al., 1979 and Friend, 1982). The presence of these complexes was identified in all the C. durissus spermatozoan regions. However, the absolute richness in complex formation agreed with the layer number of the multilaminar membranes, which means that the nucleus, that bears the most developed multilaminar membranes, was particularly marked by the presence of filipin-sterol complexes. Although many vertebrates store sperm, the phenomenon is particularly common among birds and reptiles (Gist et al., 2001). In C. durissus from southeastern Brazil, there is an asynchronism between summer spermiogenesis and autumn copulation, and sperm will be stored until the next mating season or even until the subsequent year ( Almeida-Santos et al., 2004). Besides that, after copulation, there is female sperm storage until fertilization in the spring ( Almeida-Santos and Salomão, 1997). The presence of multilaminar membranes and the particular distribution of its components may be essential to maintain sperm viability through long periods. In hamster, mouse and guinea pig spermatozoa, for example, sterols are present in the nuclear region, although restrict to the nuclear membrane, and their amount is similar to that observed in plasma membrane tapping the acrosome ( Toshimori et al., 1987). This noticeable difference between $\mathrm{C}$. durissus and these mammals may reflect their different reproductive biology. The spermatozoon of the insect Culex quinquefasciatus also presented a higher amount of filipin-sterol complexes around the nucleus (Báo and Souza, 1992). The scarcity of complexes observed in the flagellum of $C$. durissus sperm obtained from the epididymal distal portion agrees with what have been found in mammal spermatozoa and may be due to a higher motility of the gamete in this epididymal segment ( Toshimori et al., 1987 and Almeida-Santos et al., 2004).

The basic protein distribution in C. durissus sperm ultrastructure, evidenced by the EPTA technique, was similar to that found in another Squamata representative, the iguanian lizard Tropidurus itambere (Ferreira and Dolder, 2003). In the midpiece, the fibrous sheath, the pericentriolar material and the axoneme peripheral fibers were the most electron-dense structures. In many animals, the midpiece contains a basic protein accumulation, interpreted to be histones removed from the nucleus during chromatin condensation process, remained in the midpiece to participate in the rapid nuclear reorganization after egg penetration (Werner, 1975). In contrast, the marked presence of the fibrous sheath encircling the axoneme until the end of the principal piece suggests its importance in sperm motility maintenance, which would be in agreement with previous suggestions relating the elastic properties of the fibrous sheath 
with a mechanical role in spermatozoa mobility (Phillips, 1972 and Fawcett, 1975). Recent works concerning marsupial sperm have showed that the fibrous sheath has a distinct protein composition and is probably originated from cytoplasmatic proteins, but the extent of structural and biochemical similarities among mammal, reptile and bird fibrous sheath is still unknown (Ricci and Breed, 2005). The dense collar and the scarce dense bodies from the midpiece were similarly a little less stained with E-PTA, and this resemblance may be additional evidence supporting a common origin for these structures from granules developed within the cellular cytoplasm during spermiogenesis ( Hamilton and Fawcett, 1968). The acrosome region was intensely marked with E-PTA in the region corresponding to the acrosome vesicle, suggesting that basic proteins may participate of the fertilization process. In T. itambere, the subacrosomal cone and the perforatorium were the most E-PTA stained structure from the sperm head (Ferreira and Dolder, 2003), showing that the protein composition of the acrosome may vary within Squamata.

In Squamata, only Serpentes spermatozoa retain extracellular tubules (Jamieson and Koehler, 1994), albeit there is no information concerning their origin or function. Jamieson (1995) and Oliver et al. (1996), noticing the variety of multilaminar membranes among the different Serpentes species, suggested a possible transformation of the extracellular tubules into the membranous structures, without any experimental support to date. The tannic acid acts as a mordent and binds to protein molecules, contrasting particularly tubular structures (Báo et al., 1992). The axoneme microtubules of C. durissus sperm, as expected, were intensely marked with tannic acid. The extracellular tubules were marked as well, confirming their tubular nature suggested by their morphological appearance, similar to that of tubulincomposed microtubules. However, immunolabeling with monoclonal antibodies against alpha and beta-tubulin proteins, which are the main monomers organized in heterodimers to form the microtubules, showed that the extracellular tubules do not present these tubulins in their structure. In face of this absence of composition similarity between the extracellular tubules and the axoneme microtubules, we suggest the abandonment of the denomination extracellular microtubules, constantly applied in prior ultrastructural descriptions of Serpentes spermatozoa. Consequently, any miscarried comparison between the extracellular tubules and the true microtubules would be avoided. The tannic acid also evidenced the presence and the tubular nature of extracellular tubules spread in the epididymal lumen. Similar spread tubules have already been identified in other Serpentes, Anilius scytale, Bothrops jararaca, Micrurus corallinus and Sibynomorphus mikanii (Tavares-Bastos, personal communication). It is worth to mention that Báo and Dolder (1998) identified similar tubular structures spread in the lumen of the spermatheca, a female storage organ, of the fruitfly Ceratitis capitata. According to 
them, these tubules, which are a secretion product of the spermathecal cells, probably furnish an appropriate microenviroment to maintain spermatozoa viability. Further investigations may elucidate any similarity between the function of the Serpentes extracellular microtubules and those found in the female spermatozoa storage organ of this fruitfly.

The results obtained in the present work demonstrate that the utilization of electron microscopy techniques may prove extremely relevant in the study of reproductive biology, particularly in the analyses of spermatozoa ultrastructure. In relation C. durissus, similar analyses of the spermiogenesis process and sperm maturation process, as well as of spermatozoa stored in the female reproductive tract, may offer a broader panorama concerning the nature of the sperm components, and consequently, their relation with the reproductive biology of the species. To a wider extent, similar studies involving other Serpentes species may provide valuable information to the comprehension of the influence of evolutionary history and ecological constraints in sperm ultrastructure and its relation to reproduction in the group.

\section{Acknowledgements}

This study was supported by a PIBIC/CNPq fellowship to L.D.C. and by research grants from CAPES, CNPq, FINATEC and FINEP. We thank the Zoológico de Brasília, which made available the specimens and gently offered the necessary technical support. The animals were collected with authorization of the MMA/IBAMA (Ministério do Meio Ambiente/Instituto Brasileiro do Meio Ambiente; file \# 02008.001056/2006).

\section{References}

Almeida-Santos, S.M., Saloma o, M.G., 1997. Long-term sperm storage in the female Neotropical rattlesnake Crotallus durissus terrificus (Viperidae: Crotalinae). Jpn. J. Herpetol. 17 (2), 46-52.

Almeida-Santos, S.M., Laporta-Ferreira, I.L., Antoniazzi, M.M., Jared, C., 2004. Sperm storage in males of the snake Crotallus durissus terrificus (Crotalinae: Viperidae) in southeastern Brazil. Comp. Biochem. Physiol., Part A 139, 169-174.

Austin, C.R., 1965. Fine structure of the snake sperm tail. J. Ultrastruct. Res. (12), 452-462.

Báo, S.N., Lins, U., Farina, M., Souza, W., 1992. Mitochondrial derivatives of Culex quinquefasciatus (Culicidae) spermatozoon: some new aspects evidenced by cytochemistry and image processing. J. Struct. Biol. 109, 46-51.

Báo, S.N., Souza, W., 1992. Distribution of intramembranous particles and filipin-sterol complexes in the spermatid and spermatozoon of Culex quinquefasciatus (Culicidae). Biol. Cell 75, 37-44. 
Báo, S.N., Dolder, H., 1998. Ultrastructural study of the spermatheca of the fruitfly Ceratitis capitata (Diptera, Tephritidae). Braz. J. Morphol. Sci. 15 (2), 223-228.

Blackburn, D.G., 1998. Structure, function, and evolution of the oviducts of squamate reptiles, with special reference to viviparity and placentation. J. Exp. Zool. 282, 560-617.

Elias, P.M., Friend, D.S., Goerke, J., 1979. Membrane sterol heterogeneity: freeze-fracture detection with saponins and filipin. J. Histochem. Cytochem. 27, 1247-1260.

Fawcett, D.W., 1975. The mammalian spermatozoon. Dev. Biol. 44, 394-436.

Ferreira, A., Dolder, H., 2003. Cytochemical study of spermiogenesis and mature spermatozoa in the lizard Tropidurus itambere (Reptilia, Squamata).Acta Histochem. 105 (4), 339-352.

Friend, D.S., 1982. Plasma-membrane diversity in a highly polarized cell. J. Cell Biol. 93, 243249.

Furieri, P., 1970. Sperm morphology of some reptiles: Squamata and Chelonia.In: Comparative Spermatology. Academic Press, New York, pp. 115-131.

Girling, J.E., 2002. The reptilian oviduct: a review of structure and function and directions for future research. J. Exp. Zool. 293, 141-170.

Gist, D.H., Dawes, S.M., Turner, T.W., Sheldon, S., Congdon, J.D., 2001. Sperm storage in turtles: a male perspective. J. Exp. Zool. 292, 180-186.

Giugliano, L., Teixeira, R., Colli, G.R., Báo, S.N., 2002. Ultrastructure of spermatozoa of the lizard Ameiva ameiva, with considerations on polymorphism within the family Teiidae (Squamata). J. Morphol. 253, 264-271.

Hamilton, D.W., Fawcett, D.W., 1968. Unusual feature of the neck and middlepiece of snake spermatozoa. J. Ultrastruct. Res. 23, 81-97.

Harding, H.R., Aplin, K.P., Mazur, M., 1995. Ultrastructure of spermatozoa of Australian blindsnakes, Ramphotyphlops spp. (Typhlopidae Squamata): first observations on the mature spermatozoon of scolecophidian snakes. In: Jamieson, B.G.M., Ausio, J., Justine, J.-L. (Eds.), Advances in Spermatozoal Phylogeny and Taxonomy, vol. 166. Me'moires du Musse'um National d'Histoire Naturelle, pp. 385-396.

Healy, J.M., Jamieson, B.G.M., 1994. The ultrastructure of spermatogenesis and epididymal spermatozoa of the tuatara Sphenodon punctatus (Sphenodontida, Amniota). Philos. Trans. R. Soc. Lond. B 344, 187-199.

Jamieson, B.G.M., Koehler, L., 1994. The ultrastructure of the spermatozoon of the northern water snake, Nerodia sipedon (Colubridae, Serpentes), with phylogenetic considerations. Can. J. Zool. 72, 1648-1652.

Jamieson, B.G.M., 1995. The ultrastructure of spermatozoa of the Squamata (Reptilia) with philogenetic considerations. In: Jamieson, B.G.M., Ausio, J., Justine, J.L. (Eds.), Advances in Spermatozoal Phylogeny and Taxonomy, vol. 166. Me'moires du Musse'um National d'Histoire Naturelle, pp. 359-383. 
Jamieson, B.G.M., 1999. Spermatozoal phylogeny of the Vertebrata. In: The Male Gamete: from Basic Science to Clinical Applications. Cache River Press, Vienna, II, pp. 303-331.

Ladha, S., 1998. Lipid heterogeneity and membrane fluidity in a high polarized cell, the mammalian spermatozoon. J. Membr. Biol. 165, 1-10.

Lino-Neto, J., Ba'o, S.N., Dolder, H., 2000. Structure and ultrastructure of spermatozoa of Trichogramma pretiosum Riley and Trichogramma atopovirilia

Oatma and Platner (Hymenoptera: Trichogrammatidae). Acta Zool. (Stockholm) 81, 205-211.

Oliver, S.C., Jamieson, B.G.M., Scheltinga, D.M., 1996. The ultrastructure of spermatozoa of Squamata. II. Agamidae, Varanidae, Colubridae, Elapidae and Boidae (Reptilia). Herpetologica 52, 216-241.

Olsson, M., Gullberg, A., Tegelstrom, H., 1994. Sperm competition in the sand lizard Lacerta agilis. Anim. Behav. 48, 193-200.

Phillips, D.M., 1972. Comparative analysis of mammalian sperm motility. J.Cell Biol. 53, 561573.

Ricci, M., Breed, W.G., 2005. Morphogenesis of the fibrous sheath in the marsupial spermatozoon. J. Anat. 207, 155-164.

Server, D.M., Hamlett, W.C., 2002. Female sperm storage in reptiles. J. Exp. Zool. 292, 187199.

Shine, R., Bonnet, X., 2000. Snakes: a new "model organism" in ecological research? Trends Ecol. Evol. 15, 221-222.

Shine, R., 2003. Reproductive strategies in snakes. Proc. Roy. Soc. Lond. B 270, 995-1004.

Tavares-Bastos, L., Teixeira, R.D., Colli, G.R., Ba'o, S.N., 2002. Polymorphism in the sperm ultrastructure among four species of lizards in the genus Tupimanbis (Squamata, Teiidae). Acta Zool. (Stockholm) 83, 297-307.

Tavares-Bastos, L., Cunha, L.D., Colli, G.R., Ba'o, S.N., 2007. Ultrastructure of spermatozoa of scolecophidian snakes (Lepidosauria, Squamata). Acta Zool. (Stockholm) 88 (3), 189-197.

Teixeira, R.D., Colli, G.R., Ba'o, S.N., 1999. The ultrastructure of spermatozoa of the lizard Micrablepharus maximiliani (Squamata, Gymnophthalmidae), with considerations on the use of sperm ultrastructure characters in phylogenetic reconstruction. Acta Zool. (Stockholm) 80, 47-59.

Toshimori, K., Higashi, R., Chikayoshi, O., 1987. Filipin-sterol complexes in golden hamster sperm membranes with special reference to epididymal maturation. Cell Tissue Res. 250, 673680.

Tourmente, M., Cardozo, G., Bertona, M., Guidobaldi, A., Giojalas, L., Chiaraviglio, M., 2006. The ultrastructure of the spermatozoa of Boa constrictor occidentalis, with considerations on its mating system and sperm competition theories. Acta Zool. (Stockolm) 87, 25-32. 
Travis, A.J., Kopf, G.S., 2002. The role of cholesterol efflux in regulating the fertilization potential of mammalian spermatozoa. J. Clin. Invest. 110, 731-736.

Vieira, G.H.C., Colli, G.R., Ba'o, S.N., 2004. The ultrastructure of the spermatozoon of the lizard Iguana iguana (Reptilia, Squamata, Iguanidae) and the variability of sperm morphology among iguanian lizards. J. Anat. 204, 451-464.

Werner, G., 1975. Changes in the spermatozoon during fertilization in Triturus helveticus. In: Afzelius, B.A. (Ed.), The Functional Anatomy of the Spermatozoon. Pergamon Press, Oxford, pp. 47-56.

Zama, U., Moreira, J., Ba'o, S.N., Campos, L.A.O., Dolder, H., Lino-Neto, J., 2007. Morphology of testicular and post-testicular spermatozoa in Microstigmus arlei Richards, 1972 and M. nigrophthalmus Melo, 1992 (Hymenoptera: Apoidea: Pemphredoninae) with phylogenetic consideration. Arthropod Struct. Dev. 36, 304-315. 